\title{
METODE AHP DALAM PEMILIHAN STRATEGI PADA AKTIFITAS PENAMBANGAN FRONT PRODUKSI PT CSD: PENAMBANGAN FULL FACE DAN TOP HEADING AND BENCHIN
}

\author{
Sidik Muhamad $^{2)}$, Bimo Wicaksono ${ }^{3)}$, Barlian Dwinagara ${ }^{4)}$ \\ 2) Mine Plan Engineer, PT Cibaliung Sumberdaya, Banten \\ ${ }^{3)}$ Quality Control Manager, PT Cibaliung Sumberdaya, Banten \\ ${ }^{4)}$ Coordinator of Graduate Program, Mining Engineering Department, UPN “Veteran" Yogyakarta
}

\begin{abstract}
ABSTRAK
PT CSD dikategorikan sebagai marginal ore deposit dengan kadar berkisar 6 gpt mengacu pada klasifikasi kadar emas di Indonesia. Oleh karena itu, strategi penambangan menjadi pertimbangan penting untuk mendapatkan nilai yang lebih ekonomis (Purwanto, 2015). Berdasarkan laporan investigasi geoteknik, ratio tekanan in-situ vertikal dan horizontal di Cibaliung adalah 4.8 MPa:9.2 Mpa atau 1:2, yang berarti tekanan horizontal di Cibaliung dua kali lebih besar dibandingkan dengan tekanan vertikalnya (Campi dan Dugan, 2004). Secara sederhana bisa disimpukan bahwa strategi untuk mempercepat aktifitas produksi secara aman lebih baik dilakukan penambahan ketinggian pada bukaan front produksi dari pada memperlebar dimensi bukaan. Dari sudut pandang biaya pengerjaan bukaan front, biaya metode full face lebih murah ketimbang metode top heading and benching. Adapun untuk tingkat keamanan maka berlaku sebaliknya (Bin Zhu dan Xiaojing Shi, 2013). Analisa keekonomisan pada kegiatan penambangan perlu juga mempertimbangkan tonase ore yang terekstrak/perolehan logam Au untuk menentukan skema mana yang paling sesuai. Pemilihan skema penambangan menggunakan metode Analytical Hierarchy Process (AHP) dengan menggunakan tiga kriteria (kestabilan, biaya penambangan, tonase ore) dan empat pilihan skema (full face 1, full face 2, THB 1 dan THB 2). Hasil perhitungan menggunakan metode AHP didapatkan peringkat skema tertinggi sampai terendah: full face $1(0.343)$, THB $2(0.260)$, THB 1 (0.215), full face $2(0.182)$.
\end{abstract}

Kata Kunci: analisa kestabilan, studi keekonomisan, metode AHP, strategi penambangan

\begin{abstract}
PT CSD is categorized as a marginal ore deposit with ore grade around 6 ppm, based on the classification of gold grade in Indonesia. Therefore, the mining strategy is an important consideration to get a more economical value (Purwanto, 2015). Based on the geotechnical investigation report, the ratio of vertical and horizontal in-situ pressure in Cibaliung is 4.8 MPa: 9.2 Mpa or 1:2, which means the horizontal pressure in Cibaliung is twice as high as its vertical pressure (Campi and Dugan, 2004). In simple terms it can be concluded that the strategy to accelerate production activities safely is heightening rather than widening the dimension of the production stope. From the point of view of tunnel/stope construction cost, the cost of the full face method is cheaper than the top heading and benching method. As for the security level, the opposite applies (Bin Zhu and Xiaojing Shi, 2013). Economic analysis in mining activities also needs to consider the tonnage of ore extracted / Au produced for deciding which scheme is appropriate. The selection of mining schemes uses the Analytical Hierarchy Process (AHP) method using three criteria (stability, mining costs, ore tonnage) and four scheme options (full face 1, full face 2, THB 1 and THB 2). The results of calculations using the AHP method obtained the highest to lowest scheme ratings: full face 1 (0.343), THB 2 (0.260), THB 1 (0.215), full face 2 (0.182).
\end{abstract}

Key Words: stability analyses, economic study, AHP method, mining strat 


\section{A. PENDAHULUAN}

PT Cibaliung Sumberdaya merupakan salah satu perusahaan pertambangan dengan komoditi emas dan perak yang aktifitasnya dilakukan di bawah tanah. PT CSD memiliki tipe endapan ephitermal low sulphidation, geometri lebar ore berkisar antara 1-15 m, Panjang 150-250 m, dan kedalaman hingga 200-300 m di bawah permukaan. Berdasarkan geometri ore, kondisi geoteknik batuan samping, dan aspek lain nya, metode penambangan di PT CSD di lakukan dengan metode cut and fill dengan jenis underhand. Metode underhand memungkinkan untuk bisa mengekstraksi ore sambil terus melanjutkan development di level kedalaman selanjutnya. Kadar ore rata-rata di PT CSD berkisar 6 gpt, berdasarkan klasifikasi kadar emas di Indonesia dikategorikan sebagai marginal ore deposit. Oleh karena itu, strategi penambangan menjadi pertimbangan penting untuk mendapatkan nilai yang lebih ekonomis (Purwanto, 2015).

Berdasarkan laporan investigasi geoteknik, rasio tekanan in-situ vertikal dan horizontal di Cibaliung adalah 4.8 MPa:9.2 Mpa atau 1:2, yang berarti tekanan horizontal di Cibaliung dua kali lebih besar dibandingkan dengan tekanan vertikalnya (Campi dan Dugan, 2004). Secara sederhana bisa disimpulkan bahwa untuk mempercepat produksi ore lebih baik menambah ketinggian bukaan front produksi dari pada memperlebar dimensi bukaan. Dari sudut pandang biaya pengerjaan bukaan front, biaya metode full face lebih rendah ketimbang metode top heading and benching. Adapun untuk tingkat keamanan maka berlaku sebaliknya (Bin Zhu dan Xiaojing Shi, 2013). Berdasarkan hal tersebut analisa keekonomisan pada kegiatan penambangan perlu juga mempertimbangkan tonase ore yang terekstrak/perolehan logam Au. Pembahasan pada paper ini bertujuan untuk menentukan skema penambangan terbaik (skema full face dan top heading and benching) berdasarkan kriteria yang telah ditentukan (kestabilan, biaya penambangan, tonase ore). Subjektifitas dalam pengambilan keputusan dapat diminimalisir dengan menggunakan cara yang akuntabel. Metode Analytical Hierarchy Process (AHP) diyakini mampu menghasilkan pengambilan keputusan yang konsisten berdasarkan persamaan perbandingan alternatif pilihan dan kriteria yang dipilih. Metode AHP mensyaratkan untuk dilakukan penilaian skala prioritas dengan memerikan parameter yang akan digunakan.

\section{B. METODOLOGI PENELITIAN}

Metode penambangan cut and fill berada pada tubuh bijih yang memiliki kemiringan dan ukuran yang tidak beraturan, oleh karena itu sangat vital untuk mengoptimalkan operasi penambangan dan kestabilan nya (Bharti dkk, 2016). Pada blok Cibitung sudah mencapai level 16 dengan kedalaman +/- 220 m dibawah permukaan. Memasuki level 17 pada blok tersebut perlu dilakukan strategi percepatan ekstraksi ore.

Terdapat empat skema penambangan yang akan dianalisa menggunakan metode AHP untuk menentukan skema mana yang terbaik berdasarkan kriteria yang ditentukan: kestabilan, biaya penambnagan, dan tonase ore. Empat skema tersebut adalah:

1) skema full face dengan tiga tahap penambangan, tiap tahap memiliki tinggi $5 \mathrm{~m}$ dan lebar $5 \mathrm{~m}$

2) skema full face dengan dua tahap penambangan, tiap tahap memiliki tinggi $7.5 \mathrm{~m}$ dan lebar $5 \mathrm{~m}$

3) skema top heading and benching dengan dua tahap penambangan, tiap tahap memiliki ketinggian $7.5 \mathrm{~m}$. Penambangan awal dilakukan dengan tinggi $5 \mathrm{~m}$ dan lebar $5 \mathrm{~m}$ hingga mine out, kemudian dilakukan benching sedalam $2.5 \mathrm{~m}$ secara retreat. Tahap selanjutnya mengikuti tahap pertama

4) skema top heading and benching dengan tiga tahap penambangan, tahap sill drift dilakukan penambangan awal dengan ketinggian $5 \mathrm{~m}$ hingga mine out, kemudian dilakukan benching sedalam $2.5 \mathrm{~m}$ secara retreat. Dua tahap selanjutnya dilakukan menggunakan metode full face dengan tinggi $5 \mathrm{~m}$ dan lebar $5 \mathrm{~m}$. 


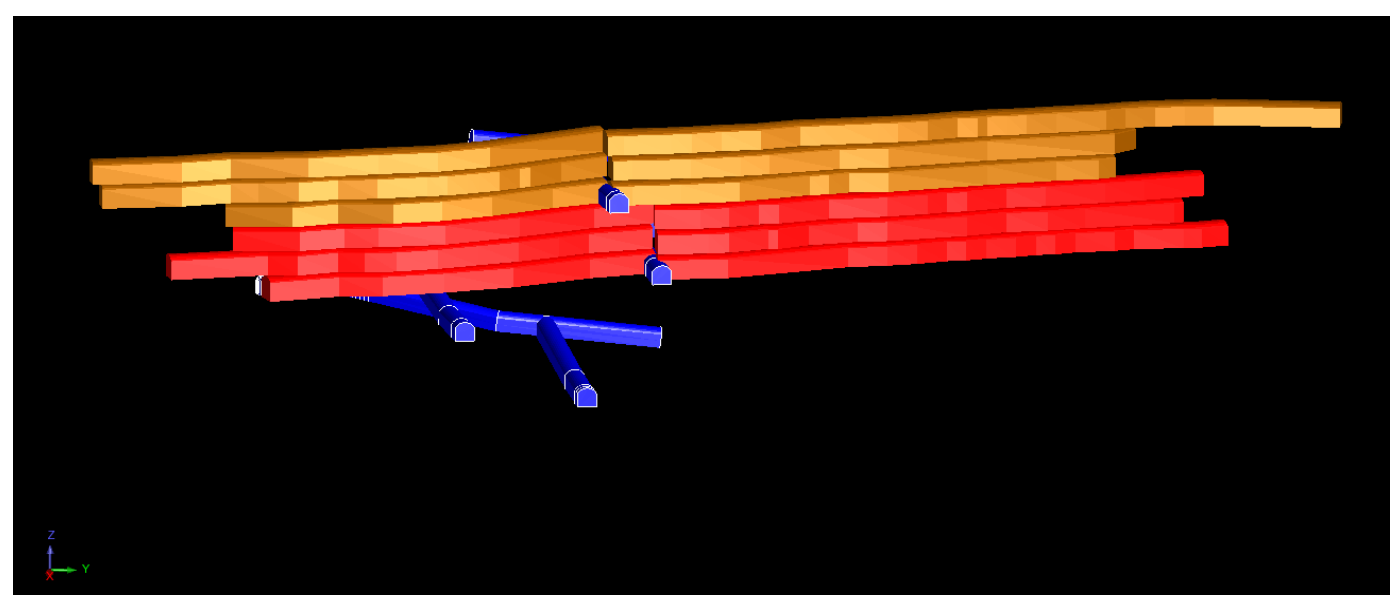

Gambar 1. Skema full face dengan tiga tahap penambangan

Gambar 1 memperlihatkan dua level penambangan dengan jarak vertikal $15 \mathrm{~m}$, tiap level memiliki tiga tahapan penambangan: sill drift, flatback, dan underconcrete tiap tahap memiliki tinggi $5 \mathrm{~m}$ dan lebar $5 \mathrm{~m}$, semua tahapan dilakukan dengan metode full face. Setelah tahap pertama (sill drift) dinyatakan mine out, maka dilanjutkan dengan pengerjaan concrete di atas lantai nya untuk kemudian diisi dengan material backfill (slurry/waste). Pengisian material slurry/waste dilakukan hingga volume nya mencapai $80 \%$ dari volume total bukaan. Setelah material slurry/waste terkompaksi maka dilakukan penambangan tahap selanjut nya (flat back). Ketika tahapan flat back dinyatakan mine out, maka dilanjutkan dengan pengisian material backfill untuk kemudian dilanjutkan dengan penambangan tahap terakhir (under concrete) pada level tersebut.

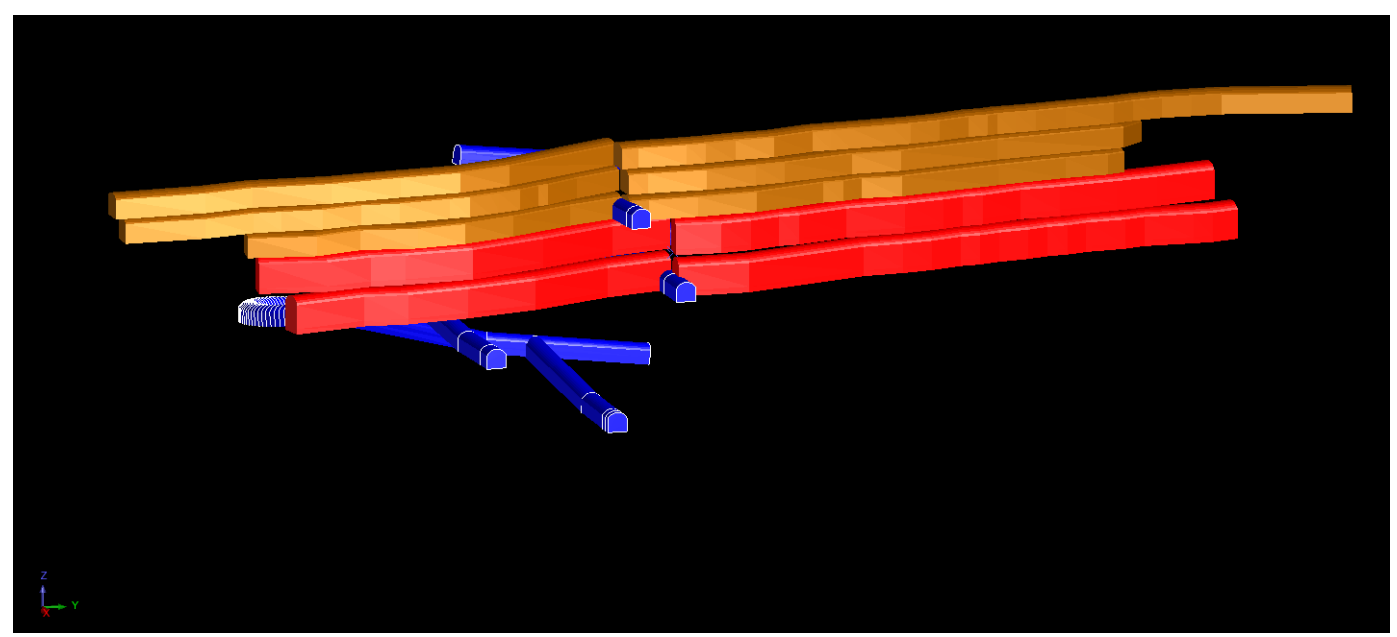

Gambar 2. Skema full face dengan dua tahap penambangan

Gambar 2 memperlihatkan dua level penambangan dengan jarak vertikal $15 \mathrm{~m}$. Pada level paling bawah memiliki dua tahap penambangan dan dilakukan dengan metode full face, tiap tahap memiliki tinggi $7.5 \mathrm{~m}$ dan lebar $5 \mathrm{~m}$ : sill drift dan underconcrete. Setelah tahap pertama (sill drift) dinyatakan mine out, maka dilanjutkan dengan pengerjaan concrete di atas lantai nya untuk kemudian diisi dengan material backfill (slurry/waste). Pengisian material slurry/waste dilakukan hingga volume nya mencapai $80 \%$ dari volume total bukaan. Setelah material slurry/waste terkompaksi maka dilakukan penambangan tahap selanjut nya (under concrete). 


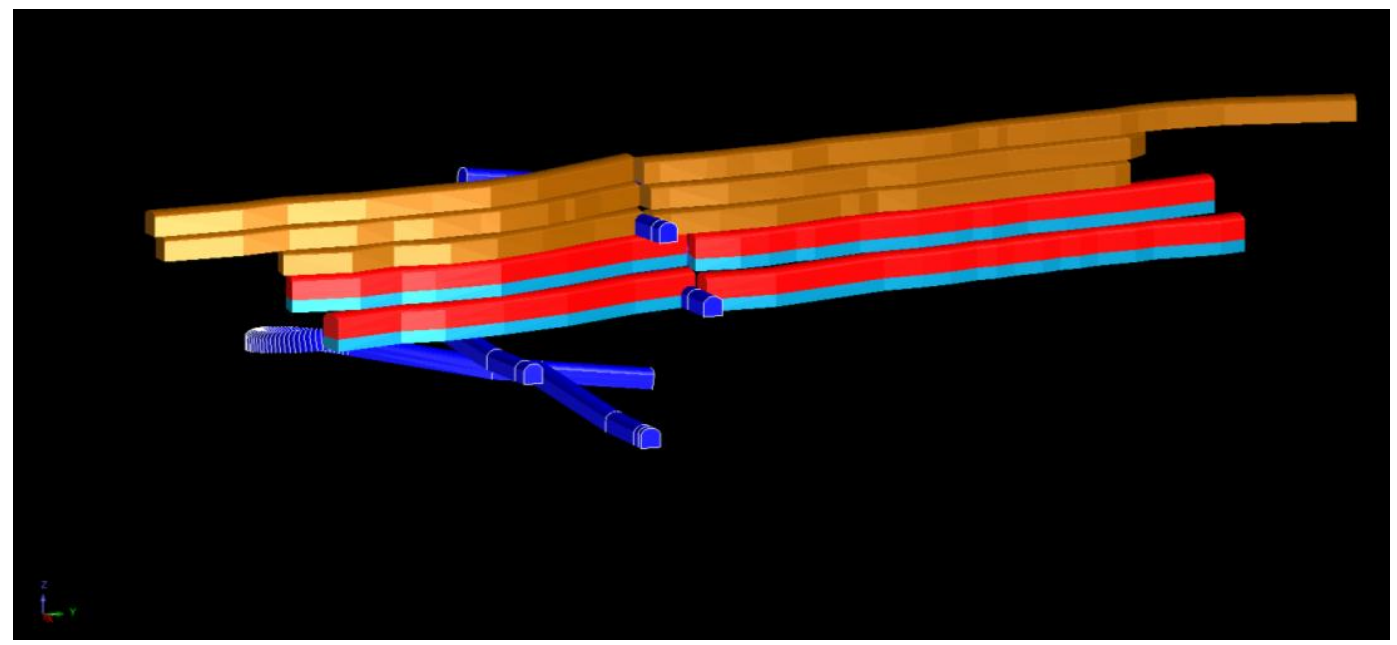

Gambar 3. Skema top heading and benching dengan dua tahap penambangan

Gambar 3 memperlihatkan dua level penambangan dengan jarak vertikal $17.5 \mathrm{~m}$. Pada level paling bawah memiliki dua tahap penambangan, tahap awal (sill drift) dilakukan dengan metode top heading and benching dengan total ketinggian $7.5 \mathrm{~m}$ dan lebar $5 \mathrm{~m}$. Pada tahapan sill drift awalnya dilakukan penambangan full face biasa: tinggi $5 \mathrm{~m}$ dan lebar $5 \mathrm{~m}$, kemudian setelah dinyatakan mine out dilakukan benching dengan kedalaman $2.5 \mathrm{~m}$ dilakukan dengan cara retreat. Setelah aktivitas benching dilakukan sampai intersection, maka dilanjutkan dengan pengerjaan concrete di atas lantai nya untuk kemudian diisi dengan material backfill (slurry/waste). Pengisian material slurry/waste dilakukan hingga volume nya mencapai $80 \%$ dari volume total bukaan. Setelah material slurry/waste terkompaksi maka dilakukan penambangan tahap selanjut nya (under concrete) mengikuti tahapan awal.

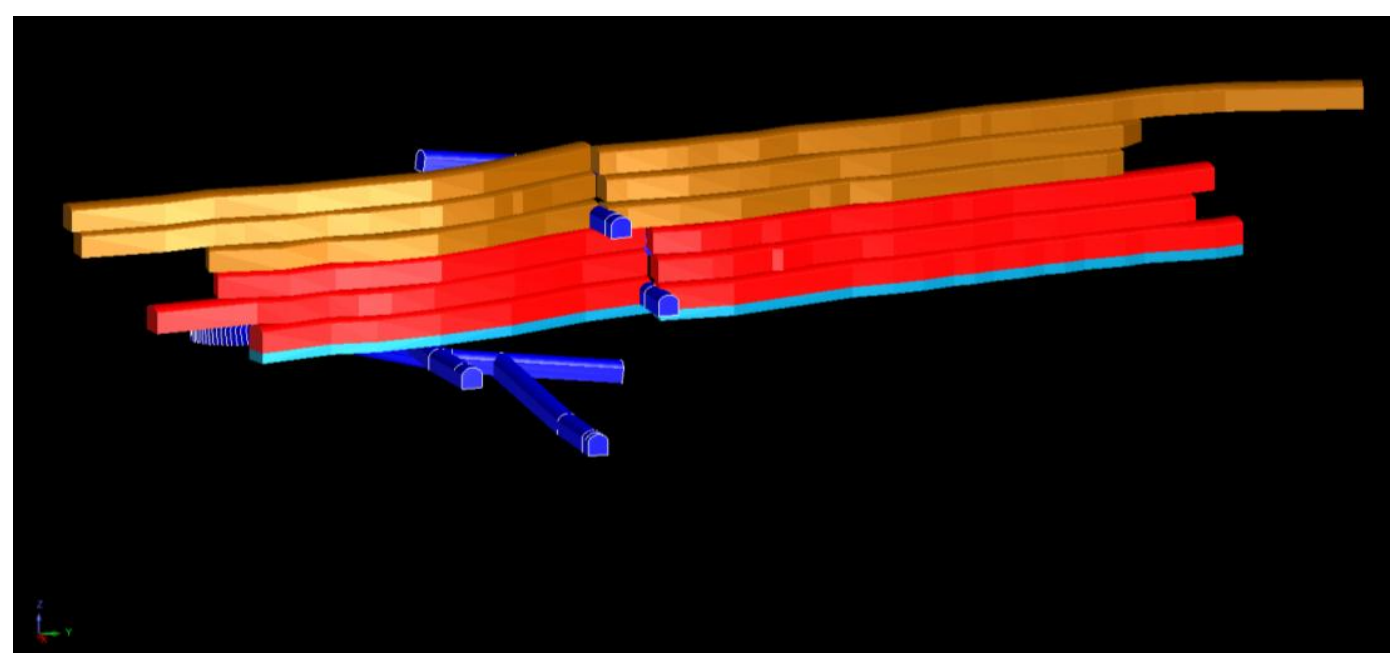

Gambar 4. Skema top heading and benching dengan tiga tahap penambangan

Gambar 4 memperlihatkan dua level penambangan dengan jarak vertikal $17.5 \mathrm{~m}$. Pada level paling bawah memiliki tiga tahap penambangan, tahap awal (sill drift) dilakukan dengan metode top heading and benching dengan total ketinggian $7.5 \mathrm{~m}$ dan lebar $5 \mathrm{~m}$. Pada tahapan sill drift awalnya dilakukan penambangan full face biasa: tinggi $5 \mathrm{~m}$ dan lebar $5 \mathrm{~m}$, kemudian setelah dinyatakan mine out dilakukan benching dengan kedalaman $2.5 \mathrm{~m}$ dilakukan dengan cara retreat. Setelah aktivitas benching dilakukan sampai intersection, maka dilanjutkan dengan pengerjaan concrete di atas lantai nya untuk kemudian diisi dengan material backfill (slurry/waste). Pengisian material slurry/waste dilakukan hingga volume nya mencapai $80 \%$ dari volume total bukaan. Setelah material slurry/waste terkompaksi maka dilakukan penambangan tahap selanjut nya (flat back). Ketika tahapan flat back dinyatakan mine out, maka dilanjutkan dengan pengisian material backfill 
untuk kemudian dilanjutkan dengan penambangan tahap terakhir (under concrete) pada level tersebut.

Analytical Hierarchy Process (AHP) adalah metode pengambilan keputusan yang mampu mengukur turunan skala rasio dari pasangan perbandingan yang bersifat discrete dan continuous. Penggunaan metode ini bersifat akuntabel dan sesuai dengan kondisi aktual berdasarkan pengamatan ahli di lapangan. Metode AHP memiliki perhatian khusus kepada penyimpangan dari konsistensi pengukuran dan ketergantungan pada dan di antara tiap kelompok elemen strukturnya. Metode ini telah menghasilkan penggunaan terluas untuk pengambilan keputusan multikriteria, perencanaan dan alokasi sumber daya, serta dalam resolusi konflik sekalipun (Saaty, 1987). Skala rasio dari parameter perbandingan dinilai berdasarkan nilai dari Tabel 1.

Tabel 1. The fundamental scale

\begin{tabular}{|c|c|c|}
\hline $\begin{array}{c}\text { Intensity of } \\
\text { importance on an } \\
\text { absolute scale }\end{array}$ & Definition & Explanation \\
\hline 1 & Equal importance & Two activities contribute equally to the objective \\
\hline 3 & $\begin{array}{c}\text { Moderate importance of one over } \\
\text { another }\end{array}$ & $\begin{array}{l}\text { Experience and judgement strongly favor one } \\
\text { activity over another }\end{array}$ \\
\hline 5 & Essential or strong importance & $\begin{array}{l}\text { Experience and judgement strongly favor one } \\
\text { activity over another }\end{array}$ \\
\hline 7 & Very strong importance & $\begin{array}{l}\text { An activity is strongly favored and its dominance } \\
\text { demonstrated in practice }\end{array}$ \\
\hline 9 & Extreme importance & $\begin{array}{l}\text { The evidence favoring one activity over another } \\
\text { is of the highest possible order of affirmation }\end{array}$ \\
\hline $2,4,6,8$ & $\begin{array}{l}\text { Intermediate values between the two } \\
\text { adjacent judgements }\end{array}$ & When compromise is needed \\
\hline Reciprocals & $\begin{array}{l}\text { If activity } i \text { has one of the above } \\
\text { numbers assigned to it when } \\
\text { compared with activity } j \text {, then } j \text { has } \\
\text { the reciprocal value when compared } \\
\text { with } i\end{array}$ & \\
\hline Rationals & Ratios arising from the scale & $\begin{array}{c}\text { If consistency were to be forced by obtaining } n \\
\text { numerical values to span the matrix }\end{array}$ \\
\hline
\end{tabular}

\section{HASIL DAN PEMBASAHAN}

Pemodelan numeris mengunakan software Phase2 dilakukan dengan membuat beberapa tahapan penggalian, sebagai berikut:

a) Stage $1=$ kondisi lubang bukaan fase awal dengan dimensi 5 x $5 \mathrm{~m}$ dengan adanya penyangga berupa liner (shotcrete dan wiremesh) serta rockbolt

b) Stage $2=$ kondisi lubang bukaan setelah dilakukan penggalian $1 \mathrm{~m}$

c) Stage $3=$ kondisi lubang bukaan dengan penggalian $1 \mathrm{~m}$ dari stage sebelumnya (total $2 \mathrm{~m}$ )

d) Stage $4=$ kondisi lubang bukaan dengan penambahan support.

Pemodelan disimulasikan dengan pendekatan properties pada blok Cibitung di level 16. Hasil pemodelan untuk masing-masing stage disajikan pada Gambar 5 sampai dengan Gambar 8. 


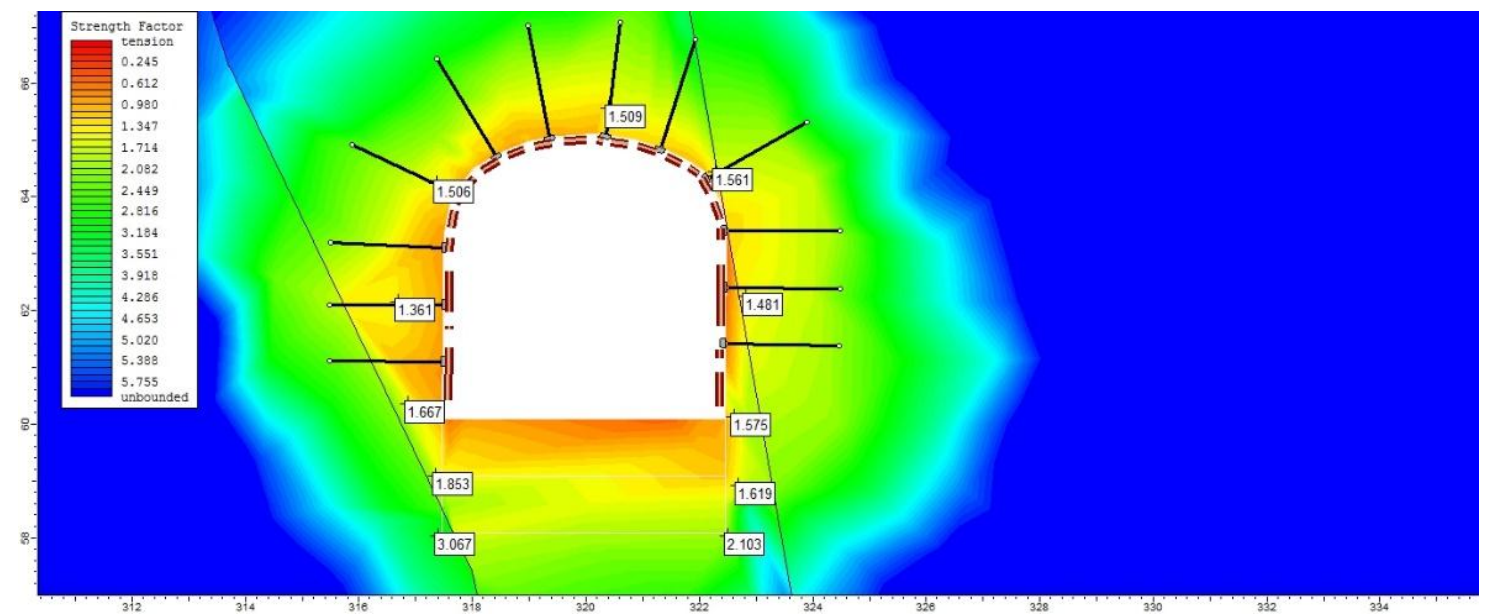

Gambar 5. Hasil Interpretasi Model Top Heading and Bench Parameter Strength Factor Stage 1

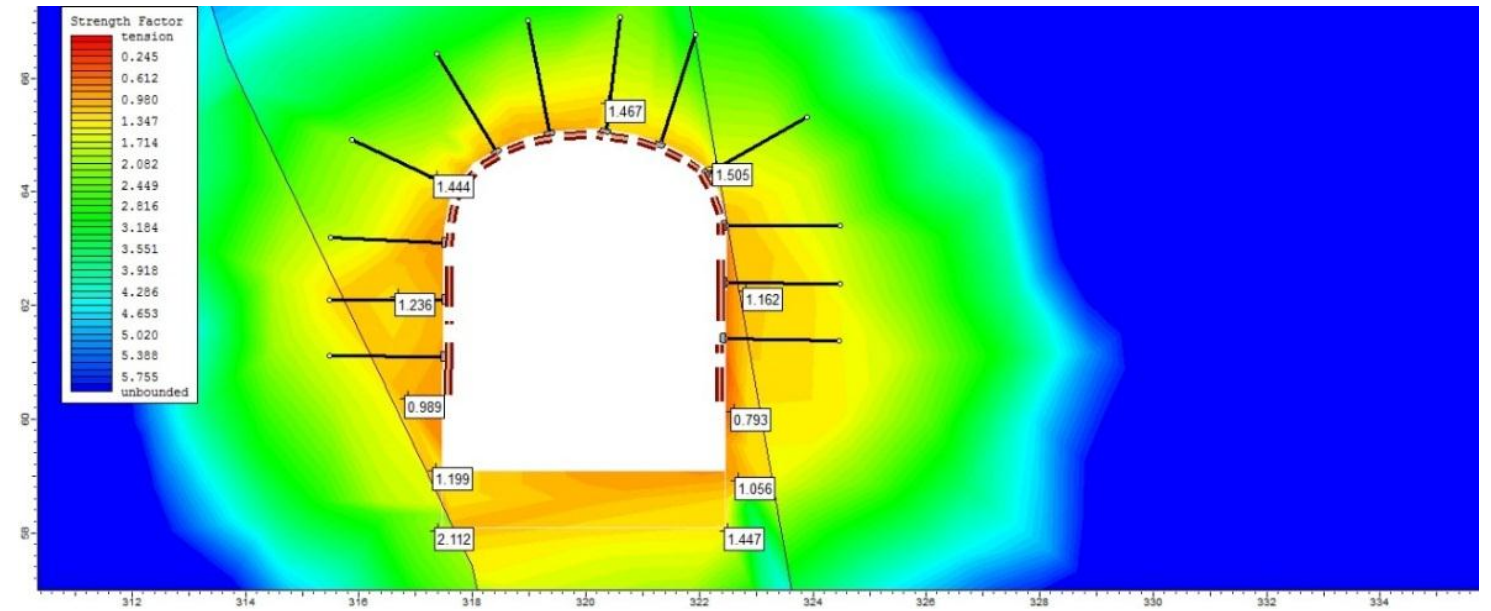

Gambar 6. Hasil Interpretasi Model Top Heading and Bench Parameter Strength Factor Stage 2

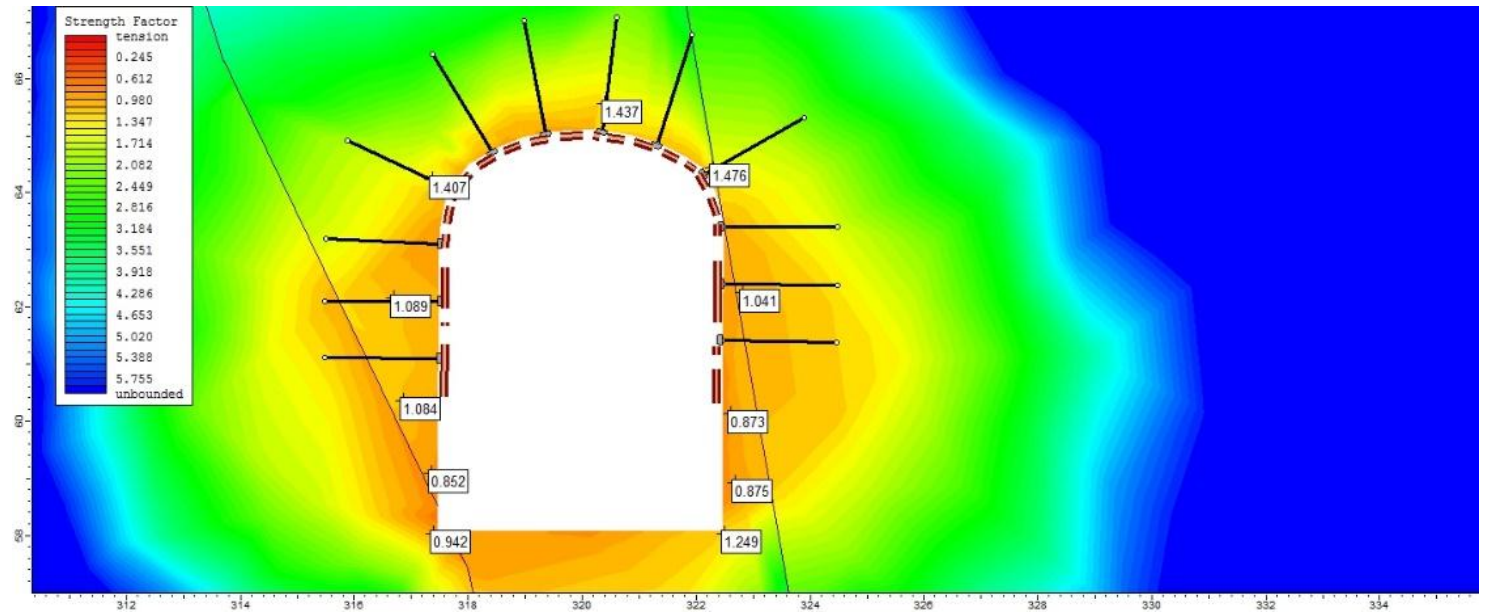

Gambar 7. Hasil Interpretasi Model Top Heading and Bench Parameter Strength Factor Stage 3 


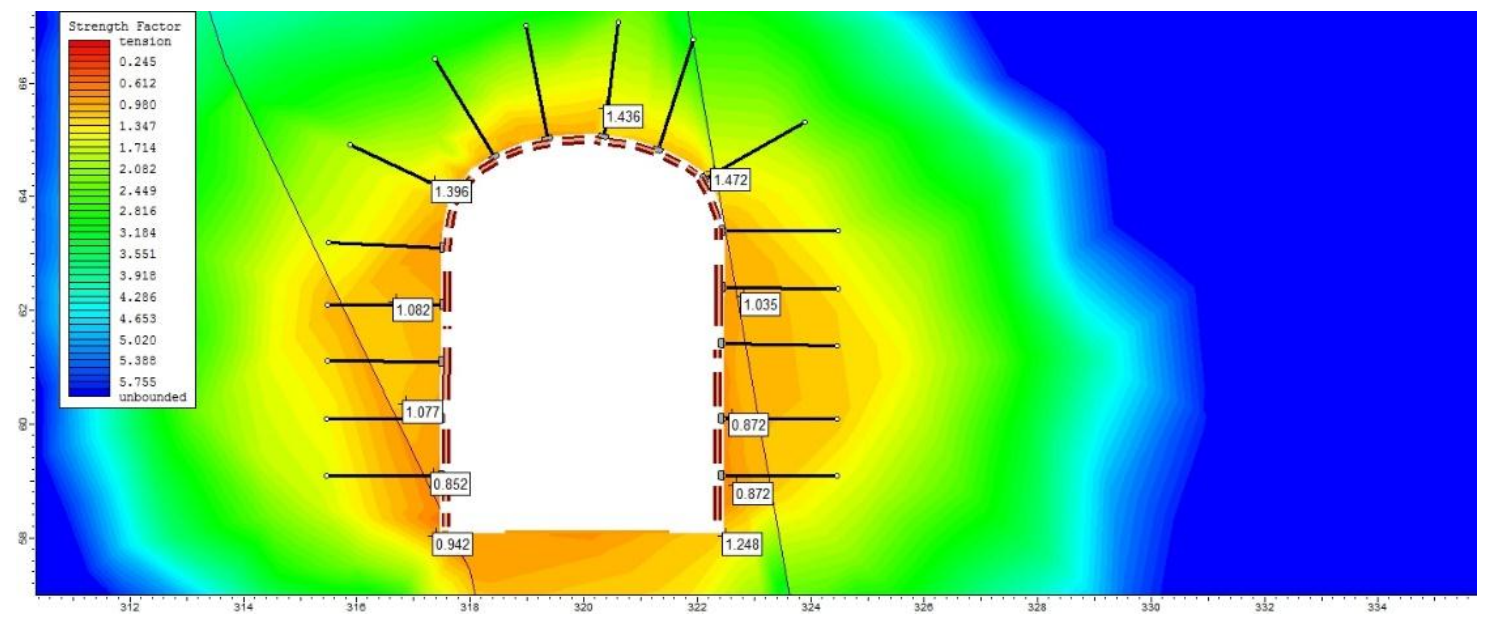

Gambar 8. Hasil Interpretasi Model Top Heading and Bench Parameter Strength Factor Stage 4

Setelah didapatkan interpretasi dari strength factor di sekeliling model lubang bukaan, maka dilakukan analisis dari perubahan nilai strength factor yang terjadi pada masing-masing stage. Pengamatan nilai strength factor dilakukan pada beberapa titik seperti yang terlihat pada Gambar 9 .

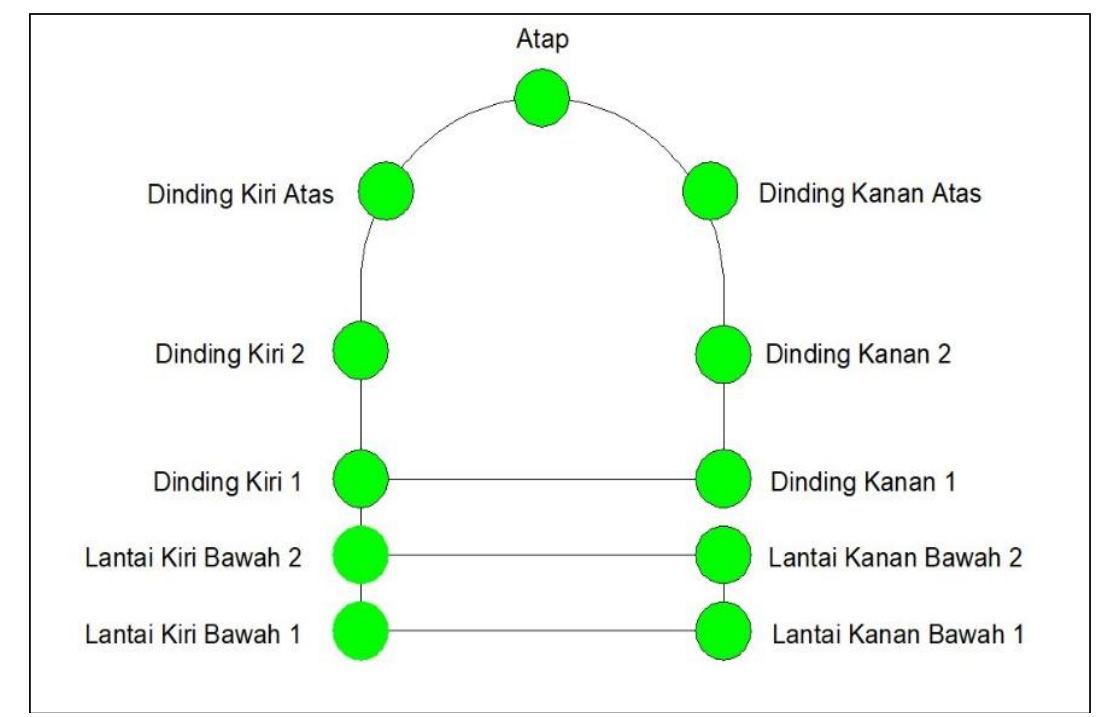

Gambar 9. Lokasi titik pengamatan nilai strength factor

Nilai strength factor pada setiap titik kemudian dirakapitulasi pada Tabel 2. Pada kondisi awal dengan dimensi lubang bukaan 5 x $5 \mathrm{~m}$, kondisi lubang bukaan masih aman. Pada stage selanjutnya, terjadi penurunan tingkat kestabilan yang cukup signifikan pada seluruh titik pengamatan, terutama pada kedua sisi dinding model lubang bukaan. Hal ini disebabkan terjadinya akumulasi distribusi tegangan pada kedua sisi tersebut. Kondisi tersebut tentunya merubah kondisi kestabilan di keseluruhan perimeter di sekitar lubang bukaan.

Terdapat tiga bagian penting dari proses analisis menggunakan metode (AHP):

a) Menyatakan tujuan analisis: pemilihan skemapenambangan

b) Tentukan kriteria: kestabilan, biaya penambangan, tonase ore

c) Tentukan alternatif pilihan: full face 1, full face 2, THB 1, THB 2

Informasi ini kemudian disusun membentuk pohon bertingkat 
Tabel 2. Nilai strength factor hasil pemodelan

\begin{tabular}{ccccc}
\hline $\begin{array}{c}\text { Lokasi titik } \\
\text { pengamatan }\end{array}$ & Stage 1 & Stage 2 & Stage 3 & Stage 4 \\
\hline Lantai kiri bawah 1 & 3.07 & 2.11 & 0.94 & 0.94 \\
Lantai kiri bawah 1 & 1.85 & 1.2 & 0.85 & 0.85 \\
Dinding kiri 1 & 1.67 & 0.99 & 1.08 & 1.08 \\
Dinding kiri 2 & 1.36 & 1.24 & 1.09 & 1.08 \\
Dinding kiri atas & 1.51 & 1.44 & 1.41 & 1.40 \\
Atap & 1.51 & 1.47 & 1.44 & 1.44 \\
Dinding kanan atas & 1.56 & 1.51 & 1.48 & 1.47 \\
Dinding kanan 2 & 1.48 & 1.16 & 1.04 & 1.04 \\
Dinding kanan 1 & 1.58 & 0.79 & 0.87 & 0.87 \\
Lantai kanan bawah 2 & 1.62 & 1.06 & 0.88 & 0.87 \\
Lantai kanan bawah 1 & 2.1 & 1.45 & 1.25 & 1.25 \\
\hline
\end{tabular}
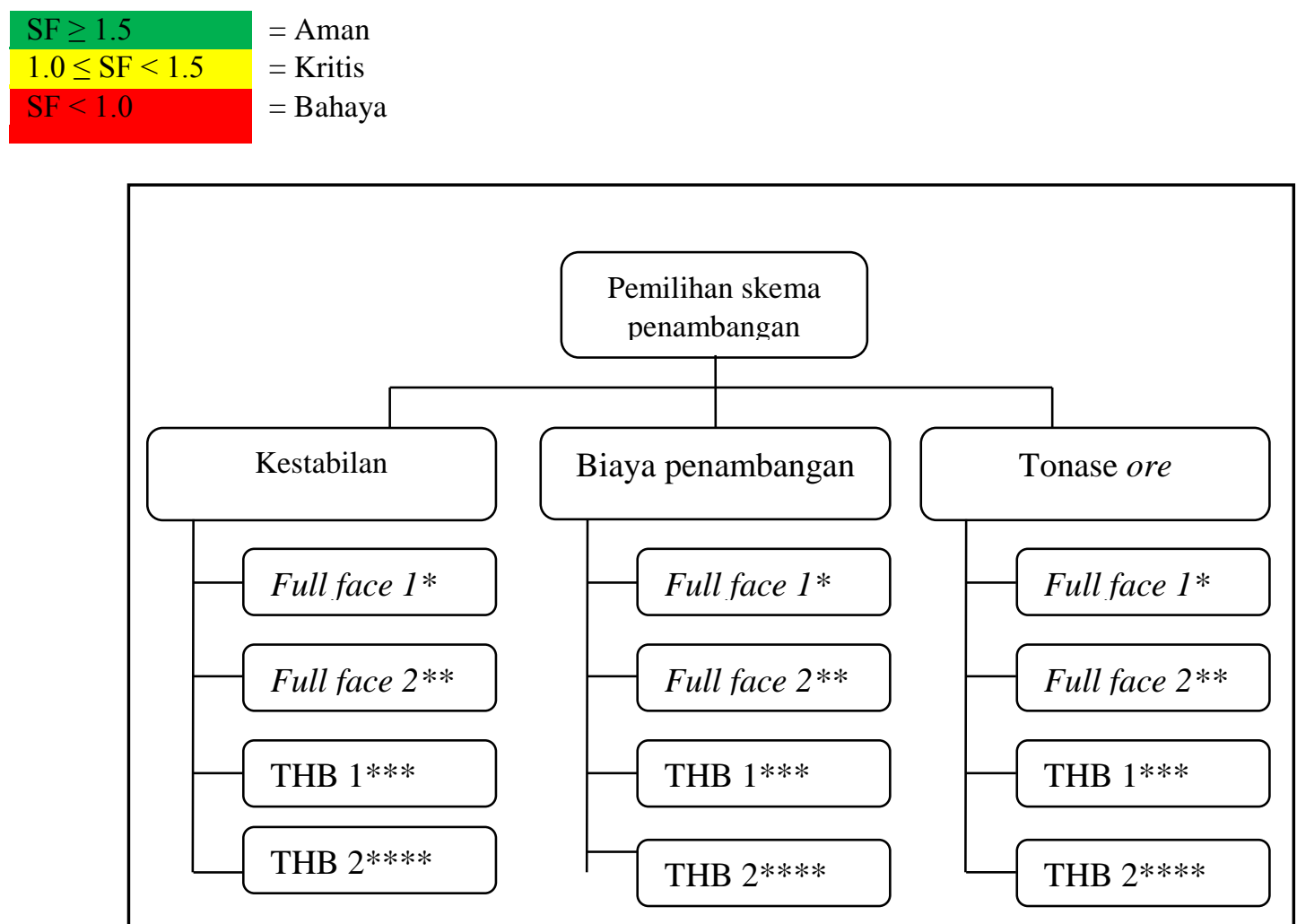

Gambar 10. Hirarki kriteria dan alternatif pilihan dari pengambilan keputusan

*skema full face dengan tiga tahapan

**skema full face dengan dua tahapan

***skematop heading and benching dengan dua tahapan

****skema top heading and benching dengan tiga tahapan

Kriteria yang ditentukan menjadi parameter penilaian kemudian disintesis untuk menentukan peringkat relatif dari alternatif pilihan yang ada. Kriteria dari jenis kualitatif dan kuantitatif dapat diperbandingkan menggunakan informed judgement untuk menghitung bobot dan prioritas. Hal ini dapat dilakukan dengan judgement untuk menentukan peringkat dari kriteria:

a) kestabilan 3 kali lebih penting dari tonase ore

b) tonase ore sama penting nya dengan biaya penambangan

c) kestabilan 5 kali lebih penting dari biaya penambangan 
Tabel 3. Kriteria perbandingan berpasangan

\begin{tabular}{cccc}
\hline Kriteria & Kestabilan & Biaya penambangan & Tonase ore \\
\hline Kestabilan & 1 & 5 & 3 \\
Biaya penambangan & $1 / 5$ & 1 & 1 \\
Tonase ore & $1 / 3$ & 1 & 1 \\
\hline
\end{tabular}

Matriks pada Tabel 2 diproses sehingga menjadi peringkat dari kriteria yang sudah ditentukan menggunakan eigenvector. Adapun langkahnya adalah sebagai berikut:

a) menggunakan matrik berpasangan sebagai dasar penghitungan kuadrat matrik berpasangan

b) jumlah setiap baris dari matriks yang telah dikuadratkan

c) normalisasi hasil penjumlahan ditiap baris

d) lanjutkan perhitungan hasil dari pengkuadratkan untuk mendapatkan nilai eigenvector kedua jika nilai masih bisa diperkecil

e) hentikan perhitungan lanjutan jika hasil pengurangan dari beberapa eigenvector bernilai minus

tahap 1 mengkuadratkan matriks berpasangan

$$
\left[\begin{array}{lll}
1.000 & 5.000 & 3.000 \\
0.200 & 1.000 & 1.000 \\
0.333 & 1.000 & 1.000
\end{array}\right] \times\left[\begin{array}{lll}
1.000 & 5.000 & 3.000 \\
0.200 & 1.000 & 1.000 \\
0.333 & 1.000 & 1.000
\end{array}\right]=\left[\begin{array}{ccc}
3.000 & 13.000 & 11.000 \\
0.733 & 3.000 & 2.600 \\
0.867 & 3.667 & 3.000
\end{array}\right]
$$

tahap 2 menjumlahkan setiap baris

$$
\begin{aligned}
3.000+13.000+11.000 & =27.118 \\
0.733+3.000+2.600 & =6.333 \\
0.867+3.667+3.000 & =7.533 \\
& =40.887
\end{aligned}
$$

tahap 3 menormalisasi nilai dari penjumlahan

$$
\begin{aligned}
& 27.118 / 40.867=0.661 \\
& 6.333 / 40.867=0.155 \\
& 7.533 / 40.867=0.184
\end{aligned}
$$

dari nilai diatas bisa disimpulkan peringkat dari kriteria sebagai berikut:
a) kestabilan peringkat ke satu
$(0.661)$
b) tonase ore peringkat ke dua
$(0.184)$
c) biaya penambangan peringkat ke tiga
$(0.155)$

tahap selanjutnya mencari peringkat dari alternatif pilihan berdasarkan kriteria yang telah ditetapkan.

Tabel 4. Perbandingan persamaan alternatif pilihan berdasarkan kestabilan

\begin{tabular}{ccccc}
\hline Kestabilan & Full face 1 & Full face 2 & THB 1 & THB 2 \\
\hline Full face 1 & 1.000 & 2.5 & 1.9 & 1.6 \\
Full face 2 & 0.400 & 1.000 & 0.714 & 0.500 \\
THB 1 & 0.526 & 1.4 & 1.000 & 0.833 \\
THB 2 & 0.625 & 2 & 1.2 & 1.000 \\
\hline
\end{tabular}

dari perhitungan eigenvector didapat peringkat alternatif pilihan berdasarkan kestabilan sebagai berikut:
a) full face 1 peringkat ke satu
$(0.389)$ 

b) THB 2 peringkat ke dua
$(0.260)$
c) THB 1 peringkat ke tiga
d) full face 2 peringkat ke empat
$(0.144)$

Tabel 5. Perbandingan persamaan alternatif pilihan berdasarkan biaya penambangan

\begin{tabular}{ccccc}
\hline Biaya penambangan & Full face 1 & Full face 2 & THB 1 & THB 2 \\
\hline Full face 1 & 1.000 & 0.833 & 1.300 & 1.500 \\
Full face 2 & 1.200 & 1.000 & 1.100 & 1.400 \\
THB 1 & 0.769 & 0.909 & 1.000 & 1.100 \\
THB 2 & 0.667 & 0.714 & 0.909 & 1.000 \\
\hline
\end{tabular}

dari perhitungan eigenvector didapat peringkat alternatif pilihan berdasarkan biaya penambangan sebagai berikut:
a) full face 2 peringkat ke satu
$(0.289)$
b) full face 1 peringkat ke dua
c) THB 1 peringkat ke tiga
$(0.231)$
d) THB 2 peringkat ke empat
$(0.200)$

Tabel 6. Perbandingan persamaan alternatif pilihan berdasarkan tonase ore

\begin{tabular}{c|cccc}
\hline Tonase ore & Full face 1 & Full face 2 & THB 1 & THB 2 \\
\hline Full face 1 & 1.000 & 1.000 & 1.000 & 0.740 \\
Full face 2 & 1.000 & 1.000 & 1.000 & 0.740 \\
THB 1 & 1.000 & 1.000 & 1.000 & 0.740 \\
THB 2 & 1.350 & 1.350 & 1.350 & 1.000 \\
\hline
\end{tabular}

dari perhitungan eigenvector didapat peringkat alternatif pilihan berdasarkan tonase ore sebagai berikut:

a) THB 2 merupakan peringkat ke satu

b) full face 1, full face 2, dan THB 1 merupakan peringkat ke dua

setelah kriteria dan alternatif pilihan mendapatkan nilai dari perhitungan udgement dari penulis berdasarkan kondisi di lapangan maka hirarki dan alternatif pilihan dari pengambilan keputusan dapat digambarkan seperti pada Gambar 15

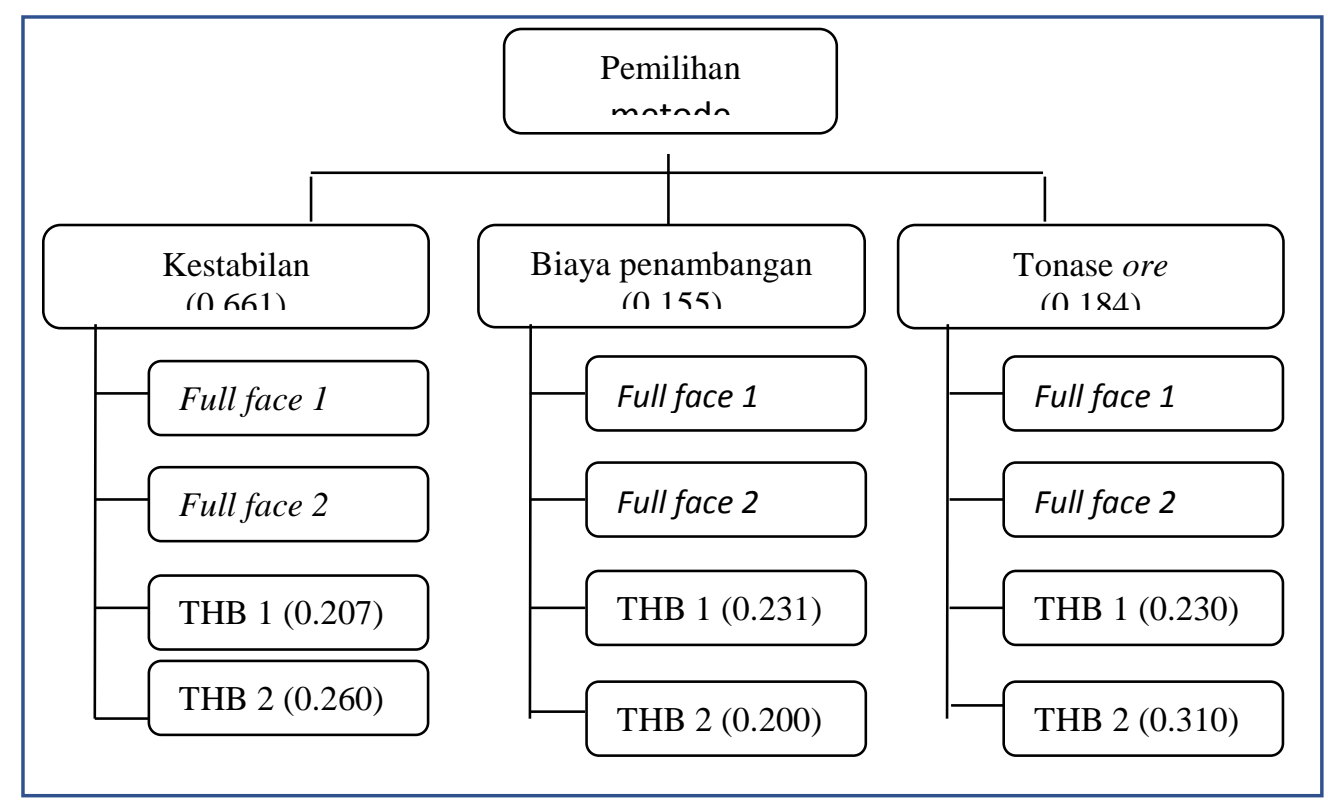


Gambar 15. Hirarki kriteria dan alternatif pilihan dilengkapi dengan nilai bobot keputusan Tabel 7. Perbandingan persamaan kriteria dengan alternatif pilihan

$\left.\begin{array}{lccc}\hline \multicolumn{5}{c}{\text { Kestabilan }} & \text { Biaya penambangan } & \text { Tonase } \text { ore } \\ \hline \text { Full face 1 } & 0.389 & 0.279 & 0.230 \\ \text { Full face 2 } & 0.144 & 0.289 & 0.230 \\ \text { THB 1 } & 0.207 & 0.200 & 0.230 \\ \text { THB 2 } & 0.260 & 0.310\end{array}\right]\left[\begin{array}{l}0.661 \\ 0.155 \\ 0.184\end{array}\right] \begin{aligned} & 0.343 \\ & 0.182 \\ & 0.215 \\ & 0.260\end{aligned}$

dari perhitungan eigenvector didapat peringkat alternatif pilihan berdasarkan semua kriteria adalah sebagai berikut:
a) full face 1 peringkat ke satu
b) THB 2 peringkat ke dua
c) THB 1 peringkat ke tiga
d) full face 2 peringkat ke empat
$(0.182)$

\section{KESIMPULAN}

Urutan skala prioritas dari kriteria yang paling penting adalah: kestabilan, tonase ore, kemudian biaya penambangan. Penggunaan metode AHP pada skala prioritas kriteria tersebut menghasilkan skema penambangan terbaik yaitu skema full face dengan tiga tahap penambangan. Jika nilai FK dari skema THB 2 bisa direkayasa untuk menyamai nilai FK skema full face 1 atau memperkecil perbedaan nilai FK nya, maka bisa dipastikan bahwa skema THB 2 akan menjadi skema dengan peringkat tertinggi karena menghasilkan tonase ore lebih banyak dari ketiga skema lain.

\section{DAFTAR PUSTAKA}

Bharti, Sujeet, Deb, Debasis, dan M., Subir., K. (2016): CUT AND FILL STOPES DESIGN AND THEIR STABILITY ANALYSIS: A CASE STUDY OF AN U/G METALLIFEROUS MINE, Department of Mining Engineering, IIT, Kharagpur, 4.

Campi, P. dan Dugan, K. (2004): Underground mine geotechnical investigation results - Volume I text and figures dalam Purwanto (2015) DESIGN OF SUPPORT SYSTEM BY OVERHAND CUT AND FILL MINING METHOD IN UNDERGROUND GOLD MINE, INDONESIA. A Doctoral Disertation, Kyushu University, 11.

Purwanto (2015) DESIGN OF SUPPORT SYSTEM BY OVERHAND CUT AND FILL MINING METHOD IN UNDERGROUND GOLD MINE, INDONESIA. A Doctoral Disertation, Kyushu University, 11.

Saaty, R. W. (1987): THE ANALYTICAL HIERARCHY PROCESS-WHAT IT IS AND HOW IT IS USED, 9, 161-176.

Zhu, Bin dan Shi, Xiaojing. (2013): Study on Construction of Long Span and Soft Rock Tunnel with Numerical Simulation, Trans Tech Publications, Switzerland, 964-967.

Tutorial dan Contoh Perhitungan AHP, diperoleh melalui situs internet: https://informasi anakutm.blogspot.com/2017/05/tutorial-dan-contoh-perhitungan-ahp.html. Diakses pada tanggal 13 September 2019. 
PROSIDING TPT XXVIII PERHAPI 2019 